\title{
NORDISK NAMNERENESSANSE I NORSKE FØRENAMN
}

\author{
GUDLAUG NEDRELID
}

\section{Innleiing}

Dei fleste nordmenn over ein viss alder veit kvar dei var då langrennsløparen Oddvar Brå braut staven i VM-stafetten i Oslo i 1982. Oddvar Brå var, og er enno i dag, ein stor kjendis. Namnet Oddvar er eit vanleg norsk mannsførenamn, med 4872 berarar i januar 2017 («Hvor mange heter», nett). Av andre kjende namneberarar i tillegg til skistjerna kan nemnast filmregissøren Oddvar Bull Tuhus, Oddvar Nygård, som var ein landskjend trekkspelar og komponist, og statsminister Odvar Nordli (statsminister 1976-1981). Namnet Solfrid kan tena som døme på eit tilsvarande namn på kvinnesida. Namnet har 3752 berarar («Hvor mange heter», nett), av dei kan nemnast skodespelaren Solfrid Heier, NRK-kjendis Solfrid Rørlien Saue og fotballspelar Solfrid Andersen Dahle. Namna Oddvar og Solfrid blir av alle oppfatta som typiske norske namn, og det er dei. Mange trur kanskje ogso at dei gamle norske namn, men då tek dei feil. Namna Oddvar og Solfrid står her som typiske døme på nylaga norske namn, og typiske døme på sokalla namnerenessansenamn. Nedanfor blir det presentert døme på nedslag av denne kulturstraumen i det norske namneforrådet.

\section{Kva er «den nordiske namnerenessansen»?}

Omgrepet står for ei utvikling i namneskikken i andre halvdel av 1800-talet og inn på 1900-talet, det at folk «oppglødde av nasjonalistiske straumdrag» tok i bruk gamle nordiske namn og former av namn som dei fann i sagaomsetjingar og $\mathrm{i}$ annan 
litteratur, som Bjørnsons bondeforteljingar (Aarset, 1982: 66 f.). Det kunne vera namn som ikkje hadde vore i vanleg bruk, som Sverre og Fridtjof, det kunne vera historiserande former av vanlege namn, som Sigurd for Sjur og Gudrun for Guro, eller det kunne vera at namn som berre var i bruk lokalt kom i bruk nasjonalt, som Ragnvald og Svanlaug (Kruken, 1993: 22 f.). I sume distrikt hadde nemleg mange nordiske namn overlevd, ikkje minst i dei indre bygdene på Agder og i Telemark (jf. Nedrelid, 1996; Haslum, 2005).

I 2004 vart det halde eit nordisk symposium om den nordiske namnerenessansen på Dømmesmoen i Grimstad. Botolv Helleland skreiv samanfatninga i konferanserapporten (Nedrelid og Schmidt, 2005). Her peikar han på at

dette materialet reflekterer ei ny åndsretning, eller tidsånd, om ein vil. Denne tidsånda har m.a. tidlegare nordisk namneskikk som eit referansepunkt. Ein faktor som utvilsamt verka med til fornya interesse for dei gamle nordiske namna, er romantikken (utheva av artikkelforfattaren). Den historiske og litterære interessa i dette straumdraget gav grobotn for dyrking av fortida. Eit anna moment som talde med, var sjølvstendestrevet, særleg i Finland, på Færøyane og i Noreg (Helleland, 2005: 143).

Svensken Roland Otterbjörk var den som lanserte termen nordisk namnerenessanse (Johannessen, 2005: 10). Margaretha Svahn meiner me heller kan kalla dei nynordiske namn (Svahn, 2005: 85). Linnea Gustafsson seier at trenden er kjenneteikna av

1. Namn som har funnits under fornnordisk tid, dvs. innan kristendomen kom til Norden.

2. Namn som senare har utvecklats ur ett nordiskt ordförråd, altså nybildningar.

3. Namn på gudar, kungar, hjältar o.s.v. från den nordiska forntiden.

4. Namn i nationalromantisk, eller göticistisk, litteratur där både författaren och läsaren ansåg, eller trodde, att de namn som användes var fornnordiska (Gustafsson, 2002: 116).

Namnerenessansen kom opp på 1800-talet, i alle fall i vårt land. Eva Meldgaard har kalla den nordiske namnerenessansen for den fyrste moderne namnemoten i Norden. Både dobbelnamnmoten og moten med å danna kvinnenamn av mannsnamn er eldre, men begge dei «var navnemoder, der passede sig ind efter opkaldelsessystemet» (Meldgaard, 1997: 102). Karakteristisk for moderne namnemotar er derimot «at forældrene vælger børnenes fornavne fra en navnegruppe, som man ikke har, eller ikke behøver at have nogen familiær, social eller kulturel tilknytning til» (ibid.).

Denne namnemoten starta, som vanleg er for namnemotar, i høgare sosiale sjikt, mellom akademikarar og byfolk. Kristoffer Kruken har funne spirer til denne moten i Christiania so tidleg som på 1820-talet, og det var velberga folk som tok i bruk slike namn på borna sine (Kruken, 1993: 22f., sjå ogso Johannessen, 2005). På 1850-talet var det vorte so vanleg at P.A. Munch fann grunn til å åtvara mot det, fordi det etter hans meining utarta til affektasjon. Som døme på affekterte namnetypar drog han 
fram namn på «Romanhelte og Historiehelte» (Munch, 1854: 44), og nordiske namn med «indbildt antik, og fra den rette Udtale og den Form, de nu efter Overgangsreglerne bør antage saa vidt muligt, forskjellig Skikkelse» (Munch, 1854: 41).

Innover på 1900-talet vart namnerenessansenamna sette opp som eit føredøme for foreldre som ynskte å skifta ut det bibelske namnematerialet med nordiske namn (Huseby, 1895: 4; Vágslid, 1932: 19). Slik kunne ein skifta ut Salomon med Sigurd, ${ }^{1}$ Abraham med Arne, Rebekka med Ragnhild. Rundt førre hundreårsskiftet og i fyrste halvdelen av 1900-talet var namnerenessansenamna vortne motenamn, og ein skifte ut namn som ein tykte var for vanlege eller for lange eller for gamaldagse eller på eikor vis ikkje fall i smak. Slik kunne Kristoffer bli til Kåre, Rasmus til Ragnvald, Anne til Aslaug og Marthe til Magnhild. ${ }^{2}$ Ei liknande utvikling går for seg i andre nordiske land.

\section{Norsk namneskikk før denne nye moten kom sivande}

I den fyrste utgåva av Norsk personnamnleksikon frå 1982 står der fleire artiklar om utviklinga i namneforrådet. Kristoffer Kruken har skrive artikkelen som heiter «Frå reformasjonen til den nordiske namnerenessansen».

I Krukens artikkel står det ogso kor mange prosentar av berarane som fordeler seg på kvart namn, og i kva landsdel dei står sterkast.

Tabell 1. 15 på topp-liste 1781-1800 (Kruken, 1982: 54 ff.)

\begin{tabular}{|c|c|c|}
\hline & Menn & Kvinner \\
\hline $\begin{array}{r}1 \\
2 \\
3 \\
4 \\
5 \\
6 \\
7 \\
8 \\
9 \\
10 \\
11 \\
12 \\
13 \\
14 \\
15\end{array}$ & $\begin{array}{l}\text { - Ola } \\
\text { - Anders } \\
\text { - Per } \\
\text { - Hans } \\
\text { - Lars } \\
\text { - Nils } \\
\text { - Jon } \\
\text { - Kristen } \\
\text { - Johannes } \\
\text { - Eirik } \\
\text { - Knut } \\
\text { - Jens } \\
\text { - Jacob } \\
\text { - Halvor } \\
\text { - Johan }\end{array}$ & $\begin{array}{l}\text { - } \text { A(n)ne/Anna } \\
\text { - Kari/Karen } \\
\text { - Berit/Berte/Brita } \\
\text { - Marte/a } \\
\text { - Ingeborg } \\
\text { - Mari(a) } \\
\text { - Mar(g)it } \\
\text { - Eli/Elen } \\
\text { - Kirsti/Kirsten } \\
\text { - Johanna } \\
\text { - Maren } \\
\text { - Inger } \\
\text { - Gunnhild } \\
\text { - Kristi/Kristina }\end{array}$ \\
\hline
\end{tabular}

${ }^{1}$ Somme av dei gamaltestamentlege namna har i si tid kanskje avløyst talemålsformer av nordiske namn. Framande namn (herunder gamaltestamentlege) har avløyst nordiske namn både ved samanblanding (som ved Salomon og Salmund, sjå NPL, 2013: 489) og ved førebokstavsoppkalling. Førebokstavsoppkalling var vorte vanleg på 1850-talet (Aasen, 1854: 46f.).

${ }^{2}$ Døme or artikkelforfattarens eiga slekt. Personane var fødde frå 1917 til 1927. 


\section{Nordiske namn og kyrkjelege namn}

Personnnamngranskarar brukar å klassifisera førenamn i to store klassar, nordiske namn og kyrkjelege namn. ${ }^{3}$ Dei som står med utheva skrift i tabellen ovanfor, er nordiske namn. Det er Ola, Eirik, Knut og Halvor på mannssida, og Ingeborg, Sigri, Inger og Gunnhild på kvinnesida. Alle dei andre namna er kyrkjelege namn. Faktisk er ogso dei fire nordiske mannsnamna kyrkjelege namn, på den måten at dei er helgennamn. Olav, Eirik og Knut er dei tre nordiske nasjonalhelgenane, og Halvard var ein lokal helgen på Austlandet i Noreg. Dei fleste av dei andre namna er det som heiter nordiske former av kyrkjelege namn, som Anders, Per, Hans, Lars, Nils og Jon. Typisk for desse er at det er nytestamentlege namn og helgennamn som har vorte nedslipte i lang tids bruk. Anders, Per, Hans, og Jon er apostelnamn, av Andreas, Peter og Johannes, Lars og Nils er helgennamn, av Laurentius og Nikolaus. Det same ser me på kvinnesida. Helgennamna dominerer, med Anna/Anne, Kari og Brita som dei fremste, av helgennamna Anna, Katarina og Birgitta, saman med dei nytestamentlege namna Marta og Maria. Me ser ogso at det kome inn fleire former som går attende på same namnet. Jon er norsk og vestnordisk form av Johannes. Hans, som kom inn og vart populært i seinmellomalderen, er tysk form av Johannes, og Jens er dansk form. Fem av dei 15 mest populære namna på mannssida i 1801 er former av Johannes, og dei er understreka i tabell 1.

Når Johannes og former av det namnet vart so populært, kan grunnen mellom anna vera at det var to viktige personar i Det nye testamentet som bar namnet, både evangelisten Johannes og Johannes døyparen. Institut for Navneforskning i København opplyser at «Ingen anden person i den kristne verden har gennem tiden fået opkaldt så mange drengebørn efter sig» (Navneforskning, nett).

Populariteten til dei gamle kyrkjelege namna på mannssida kan me i noko mon avlesa i lista over vanlege etternamn i dag, fordi store delar av det norsk folk går rundt med sekundærpatronymikon («-sen-namn») som slektsnamn. Dei framstår som søner av oldefar sin eller tippoldefar sin (-sen står for son).

Helgennamna og dei nytestamentlege namna kom inn med kristendommen og vart populære utover i høgmellomalderen. I seinmellomalderen kom det inn mange tyske namn og tyske former, og utover i etterreformatorisk tid vart ogso gamaltestamentlege namn populære. Men dei vanlegaste førenamna i 1801 var, som me har sett, framfor alt nordiske former av eldre kyrkjelege namn. Dei vanlegaste namna var ogso veldig vanlege, 13,4\% for Ola og 14,5\% for Anne (Kruken, 1982: 54 f.). Til samanlikning omfattar dei populæraste namna i dag, Jan og Anne, ca 2\% og $2,5 \%$ av folkemassen ( $«$ Hvor mange heter», nett). So det er ikkje det minste merkeleg at folk på 1800-talet byrja å sjå seg om etter nye namn. Me har høyrt om at dei gamaltestamentlege namna kom inn, og utover på 1800-talet kom det ogso ei bølgje

\footnotetext{
${ }^{3}$ Ofte har dei ogso vorte kalla framande namn, ma. i Aasens namnebok (Aasen, 1878: 71).
} 
av moveringar, oftast kvinnenamn avleidde av mannsnamn, særleg med etterfestet -ine, som Monsine, Hansine, Wilhelmine osv. Dei som skreiv om namneskikk på 1800-talet merka seg dette, og dei var ikkje glade for det (sjå t.d. Aasen, 1878: 92 ff.; Støylen, 1887: X ff.).

Tabell 2. Norske etternamn i fallande frekvens (Veka, 2016: 624)

\begin{tabular}{|c|c|}
\hline \multicolumn{2}{|c|}{25 på topp-liste over norske etternamn i 2015} \\
\hline Hansen & 53011 \\
\hline Johansen & 50088 \\
\hline Olsen & 49303 \\
\hline Larsen & 37869 \\
\hline Andersen & 37025 \\
\hline Pedersen & 35145 \\
\hline Nilsen & 34734 \\
\hline Kristiansen & 23397 \\
\hline Jensen & 22879 \\
\hline Karlsen & 21234 \\
\hline Johnsen & 20650 \\
\hline Pettersen & 20101 \\
\hline Eriksen & 19136 \\
\hline Berg & 18080 \\
\hline Haugen & 14346 \\
\hline Hagen & 14073 \\
\hline Johannessen & 13286 \\
\hline Andreassen & 12100 \\
\hline Jacobsen & 11906 \\
\hline Dahl & 11503 \\
\hline Jørgensen & 11426 \\
\hline Halvorsen & 11418 \\
\hline Henriksen & 11339 \\
\hline Lund & 11250 \\
\hline Sørensen & 10725 \\
\hline
\end{tabular}

\section{Interesse for namn midt på 1800 -talet}

Rundt 1850 byrja lærde menn å publisera artiklar om personnamn i ålmenne og folkeopplysande tidsskrift. P.A. Munch var den fyrste, med to artiklar i Norsk FolkeKalender i 1849 og 1854, og Ivar Aasen fylgde etter med to artiklar i Folkevennen 
i 1854 og 1855. Munch kjem att med ei lang utgreiing i Norsk Maanedsskrift i 1857. Eilert Sundt har ein artikkel om «Sprogets Bygdeskikke» i 1864, og M.A.L. Aabel har ein om «Norrøne Namn» i 1867, begge i Folkevennen. Ivar Aasens Norsk Navnebog frå 1878 kom i forlenginga av denne debatten, og ho kom som eit svar på uttrykte $\varnothing$ nskje: «Jeg skulde $\varnothing$ nske at se trykt og udbredt i Landet (...) en 10.000 eller 20.000 Exemplarer af et Ark, som indeholdt et Register paa tækkelige og rimelige Navne» (Sundt, 1864:116). Boka skulle vera hjelpa til å bøta på om det som det som vart oppfatta som skavankar og utvokstrar i namneskikken.

\section{Ivar Aasens namnebok}

Ivar Aasens Norsk Navnebog var den fyrste namneboka i Noreg, og ho har hatt stor innverknad på seinare namneskikk (jf. Nedrelid, 1997: 44 f.). Aasen var ikkje særleg oppglødd for nylaga namn, det kjem særleg fram i artiklane hans frå 1850-talet, der han skriv om «forvanskede», og «nye og forfuskede» namn (Aasen, 1854: 35f.), og haldninga er den same i 1878. Men i underkapitlet «Om Navnenes Form eller Dannelse», der han gjev oversyn over ulike føreledd og etterledd i manns- og kvinnenamn, slår han sjølv til lyd for nydanning. Aasen peikar her på det potensialet som ligg i å kombinera eksisterande namneledd til nye namn, for slik å få meir variasjon i namneskikken. «Og hvorfor skulde vi ikke have flere Navne med 'run' end bare Gudrun og maaske Oddrun? Det kunde ogsaa gaa an at hedde Ulvrun, Dagrun, Hallrun, Salrun, Sigrun, Tjodrun, Valrun, Vilrun og Øyrun» (Aasen, 1878: 56 f.).

Tabell 3. Ulike namneledd (Nedrelid, 2005b: 70)

\begin{tabular}{|l|l|}
\hline \multicolumn{2}{|c|}{ Namneledds-«bank» } \\
\hline Bruksområde & Namneledd ${ }^{4}$ \\
\hline Føreledd & $\begin{array}{l}\text { An(n)-, Arn-, As-, Aud-, Bot-, Bryn-, Dag-, Gis-, Gud-, Her-, Ing(e)-, Jo(r)-, } \\
\text { Kol-, L(e)id-, Magn-, Ragn-, Sig-, Sal-, Sol-, Tjod-, Val-, Øy-, As-, }\end{array}$ \\
\hline Føre- og etter-ledd & $\begin{array}{l}\text { Al(v)-/-alv, Ar-/-ar, Ber(g)-/-berg, Borg/-borg, Bjørg-/-bjørg, Finn/-finn, Fred-/ } \\
\text {-fred, Frid-/-(f)rid, Gerd-/-gerd, Geir/-geir, Grim-/-grim, Gunn-/-gunn, Hall-/ } \\
\text {-hall, Hild-/-hild, Kjell-/-kjell, Leiv/-leiv, Leik-/-leik, Møy-/-møy, Nor-/-nor, } \\
\text { Odd/-odd, Stein/-stein, Tor-/-tor, Ulv-/-ulv, Ve-/-ve, Vig-/-vig, Vil- } \\
\text { /-vil(d) }\end{array}$ \\
\hline Etterledd & $\begin{array}{l}\text {-dis, -gar(d), -lak, -laug, -mann, -mar, -mund, -ny, -olv, -rid, -run, -vald, } \\
\text {-var(d), -veig, -vid(ved), -vin(d), -vor }\end{array}$ \\
\hline
\end{tabular}

\footnotetext{
${ }^{4}$ Lista over namneledd skal illustrera systemet, og ho er på ingen måte fullstendig. Ledda er sette opp med dei moderne formene, slik at td. As- og Ås- (osv.), -frid og -rid (osv.) står oppførde som ulike ledd, sjølv om dei har same etymologiske opphav.
} 
Ved hjelp av variasjonsprinsippet (Storm, 1893: 203 f.) kan ein generera eit utal nye namn ved å kombinera gamle og (eventuelt nye) samansetjingsledd. Berre fantasien set grenser. Dette har ogso vorte gjort i ettertida, og eksempelnamna Oddvar og Solfrid er døme på vellukka resultat av denne prosessen.

\section{Endring i oppkallingsskikken}

Nye namn fekk innpass fordi oppkallingsskikken var i endring, med både førebokstavsopp-kalling, moveringar og fleire førenamn på same personen. Førebokstavsoppkalling er kjend frå midten av 1800-talet:

Thi paa de Steder, hvor fremmede Navne ere mest i Brug, pleier man gjerne at tage det meget løseligt med Opkaldelsen, saa at man tidt lader sig nøie med den første Stavelse af Navnet, f. Ex. Anna efter Andreas; ja at man endog stundom lader sig nøie med den første Bogstav f. Ex. naar man kalder Johan efter Ingebrigt (Aasen, 1854: 47).

Aasen, som elles var sterkt kritisk til endring i namneskikken, tilrår i 1854 førebokstavsoppkalling for å «nasjonalisera» namnetilfanget, «man kunde sætte Bjørn i Stedet for Bernt, Jostein for Jokum, Magnhild for Maret o.s.v.» (1854: 47). ${ }^{5}$ Rådet blir ført vidare av Vágslid (1932: 19). Førebokstavsoppkalling opnar for at ein kan endra namnet, og ein bestefar som heitte Anders, kunne oppkallast som Agnar og Arne og Arnulf og Atle, i staden for at der skulle vera fire Anders-ar. Ei bestemor Gjertrud blei oppattkalla som Gunnlaug, Gullborg og Gudlaug (fødde frå 1944 til 1952). ${ }^{6}$

Førebokstavsoppkalling mogeleggjer ogso oppkalling over kjønnsgrensa. Aasen hadde ikkje mykje sans for den skikken, «da kan der ikke blive nogen rigtig Lighed mellem den gamle og den unge; den sidste bliver ikkje noget forynget Billede af den første, og Opkaldelsen har altsaa ikkje noget stort at betyde» (1878: 99). Der har folk flest hatt eit anna syn på saka, og oppkalling over kjønnsgrensa har vore ei viktig kjelde til fornying i namneforrådet (meir utførleg om dette i Nedrelid, 2005a). Store syskenflokkar gav ogso høve til å velja nye namn til dei yngste, når den viktigaste oppkallinga var unnagjord. Vidar Haslum har dokumentert at på Agder og i Telemark vart gamle nordiske namn haldne oppe i relativt stort omfang, på grunn av sterk oppkallingstradisjon. Men det var klare skilnader på kva typar namn det eldste og det yngste barnet av same kjønn fekk. I perioden 1880-1940 vart eldsteborna i eit syskenlag som regel oppkalla etter besteforeldra, og dei fekk derfor tradisjonelle arvenamn. For yngstebarn var det motsett, dei fekk i stor grad motenamn/renessansenamn (Haslum, 2005).

\footnotetext{
${ }^{5}$ Meir om Aasen og den nasjonale namnerenessansen i Nedrelid, 1997.

${ }^{6}$ Men ikkje Gjertrud, for det tykte foreldregenerasjonen var eit håplaust gamaldags namn.
} 


\section{Tilpassa former av norrøne namn}

Lat oss gå attende til Gustafssons ulike typar av nordiske namnerenessansenamn. Vidareføring av eldre nordiske namn, i tilpassa former, er kanskje den vanlegaste måten. Namn som hadde «overlevd», hadde fătt nedslitne talemålsformer, på same måten som dei kyrkjelege namna. Som me har sett, blei namnet Nikolaus til Nils, og Katarina blei til Kari. På same måten blei Ólafr til Ola, og Ragnfríðr blei til Randi. Desse tradisjonsformene lever vidare, jamsides med dei nye, «tilpassa» formene. Dei norrøne namna vart nemleg tilpassa moderne rettskriving. Bokstavane P- og -ð vart ikkje brukte, det vart ikkje brukt lengdestrek over vokalane og sjølvsagt ikkje kasusmarkering. P- vart attgjeven som T- eller Th- (Torvald eller Thorvald), -ð blei (stum) -d eller ingenting (Astrid og Astri). Utlydande -f kunne bli skriven -f eller -v (Leif og Leiv). Dermed fekk ein fleire former av same namnet som etterkvart kom til å bli oppfatta som ulike namn (sjå døme nedanfor). I dag finst det til dømes 9314 menn som heiter Ola, 31372 heiter Ole som fyrste førenamn, ${ }^{7} 14993$ heiter Olav, og 2189 heiter Olaf («Hvor mange heter», nett).

Tabell 4. Døme på gamle og nye former

\begin{tabular}{|l|l|l|l|}
\hline Norrøn form & \multicolumn{1}{|c|}{ Dialektformer } & Evt. dansk skriftform & \multicolumn{1}{|c|}{ Nye former } \\
\hline Ólafr & Ola & Ole & Olaf, Olav \\
\hline Sigurðr & Sjur & & Sigurd \\
\hline Guðrun & Guro & & Gudrun \\
\hline Sigríðr & Siri & & Sigri(d) \\
\hline Porleifr & $\begin{array}{l}\text { Taddei, Taddeiv, Talleiv, Tallev, Telleiv, } \\
\text { Tellev, Tolleiv, Tollev, Tolli, Tøllev, Tølløv }\end{array}$ & & $\begin{array}{l}\text { Thorleif, Thorleiv, } \\
\text { Torleif, Torleiv }\end{array}$ \\
\hline
\end{tabular}

\section{Nylagingar på grunnlag av gamle nordiske namneledd}

Som me har sett ovanfor, argumenterte Aasen for slike nydanningar (1878: 56 f.), sameleis Støylen (1887: X). Ein studie av dei føreledda som Aasen nemner i sitt forslag (Ulv-, Dag-, Hall-, Sal-/Sol-, Sig-, Tjod-, Val-, Vilr- Øy-) viser at det finst det 50 nylaga namn, 25 mannsnamn og 25 kvinnenamn, i Kruken og Stemshaug 1995.

\footnotetext{
${ }^{7}$ Når Ole er meir populært åleine enn dei tre andre til saman, heng det saman med at det er mykje brukt som fyrstenamn i dobbeltnamn. Det er 5346 menn som har Ole som einaste førenamn. Dei andre 26008 har det som fyrstenamn i kombinasjonar som Ole Andreas, Ole Bernt, Ole Edvard, Ole Henrik, Ole Jørgen, Ole Petter og mange, mange fleire Ole + eitkvart. Til jamføring har 6936 menn Ola som einaste førenamn. Om me ser på bruken som einaste førenamn, er rekkjefylgja Olav (9641 berarar), Ola (6936) og Ole (5346).
} 
Eller rettare, det finst 50 nylaga namn til sju av forledda, for Tjod- og Ulv- er ikkje brukte som føreledd i nylagingar (Nedrelid, 2005b: 67). Me ser at det er svært ulik fordeling på dei ulike namneledda:

Tabell 4. Nydanningar med føreledda i Aasens forslag (Nedrelid, 2005b: 62)

\begin{tabular}{|c|c|c|c|}
\hline \multicolumn{4}{|c|}{ Nydanningar med føreledda i NPL (1995-utgåva) } \\
\hline & Mannsnamn & Kvinnenamn & \\
\hline Dag- & $\begin{array}{l}\text { Dagbart, Dagbjart, Dagbjørn, Dagfred, } \\
\text { Dagmund, Dagnar, Dagnor, Dagulv, } \\
\text { Dagvald, Dagvard, Dagvin }\end{array}$ & $\begin{array}{l}\text { Dagbjørg, Dagfrid, Daghild, Dagunn, } \\
\text { Dagveig }\end{array}$ & 16 \\
\hline Hall- & Hallmar & Hallgunn & 2 \\
\hline Sal-/Sol- & Salmar, Soland, Solbjørn, Solvar & $\begin{array}{l}\text { Salmøy, Solbrit, Solfrid, Solgerd, Sol- } \\
\text { gunn, Sollaug }\end{array}$ & 10 \\
\hline Sig- & Sigfinn, Signar, Signor, Sigstein, Sigtor & Sigdis, Sigfrid, Sigunn & 8 \\
\hline Tjod- & & & - \\
\hline Ulv- & & & - \\
\hline Val- & Valdon, Valdor & Valfrid, Valmøy, Valny & 5 \\
\hline Vil- & Vilmar & Vildis, Vilfrid, Vilgunn, Vilrun & 5 \\
\hline$\varnothing y-$ & Øyvard & Øyfrid, Øygunn, Øyrun & 4 \\
\hline & 25 & 25 & 50 \\
\hline
\end{tabular}

Føreleddet Dag- har vore mest brukt i nydanningar, deretter Sal-/Sol-, truleg fordi desse gjev mest positive assosiasjonar. Mange av namna i oppsettet her er svært uvanlege, men Solfrid har i alle fall slege gjennom på landsbasis.

\section{Namn etter gudar, heltar og kongar}

Sjølve paradeeksempelet på eit slikt namn er mannsnamnet Fridtjov eller Fridtjof/Frithjof (sjå ovanfor om $\langle$ p $>$ som $<$ th $>$ og $\langle$ f $>$ som både $\langle$ f $>$ og $\langle$ v $>$ ) av norront Friðpiófr. Det er eit «fingerat» namn (Lind, 1905-15: 288), namnet på helten i fornaldarsoga om Fridtjov den frøkne. I 1825 kom Esaias Tegners Frithiofs saga ut i Sverige. Allereie i 1830 vart namnet teke i bruk i Arendal, Borre og Trondheim, og på 1840-talet var det vorte vanleg i Oslo (NPL, 2013: 171). I 1858 kom Ivar Aasens omsetjing av fornaldarsoga om Fridtjov til landsmål som tilleggshefte til Folkevennen. Fridtjof Nansen vart fødd i 1861, og hans bragder på mange område, som polarforskar, vitskapsmann, diplomat og filantrop (sjå Fridtjof Nansen, snl, nettversjonen) har tvillaust auka populariteten til namnet, sjå kurve nedanfor. 
Tabell 5. Namnet Fridtjof («Hvor mange heter», nett)

\section{Fridtjof}

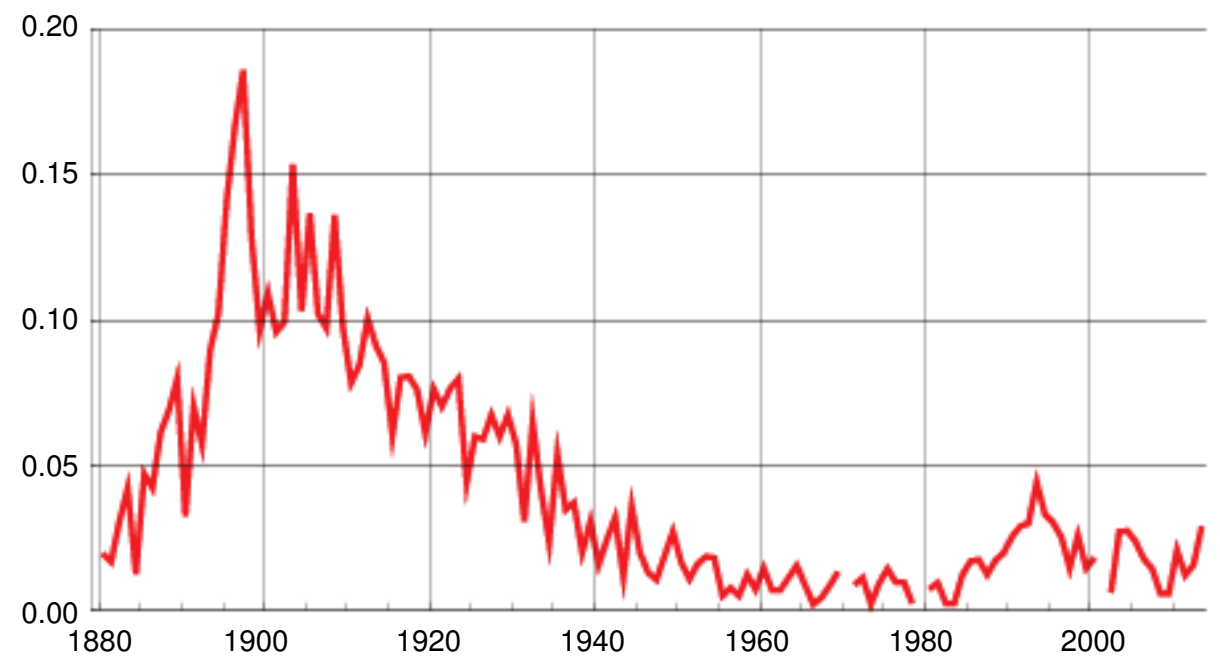

Prosent

Med gudenamn tenkjer ein straks på Tor og Odin, men dei er ikkje pålitelege døme i denne samanhengen. Mannsnamnet Tor er ikkje identisk med namnet til guden Tor (norr. Pórr), det kjem av det norrøne mannsnamnet Pórðr. Gudenamnet Pórr er føreledd (Pór-) i svært mange namn, både manns- og kvinnenamn, og dei har halde seg merkeleg godt, særleg i indre bygder (jf. Nedrelid, 1996). Det er ikkje færre enn 15 spalter i NPL med føreleddet Tor-, og dertil kjem former som Tallak og Tarjei og Terje og Tollev osv. Mannsnamnet Pórðr er opphavleg, *Pórfrøðr, med Pór- som føreledd. Uttalen i vest- og nordnorsk blir Tor, i austnorsk Tol (med tjukk /1/). På 1800-talet vart det tradisjonelle $T(h)$ or delvis omtolka til gudenamnet, samtidig som det fekk sjølvsendig status ved sida av Tord (NPL, 2013: 558 ff.). Mannsnamnet Odin (Oden, Odhinn) i eldre tid er truleg former av Audun. «Namnet til diktaren Odin (Ouden) H. Wolff (1733-1810) kan vere ei tidleg omtolking frå Audun til Odin» (NPL, 2013: 426). Gudinnenamnet Frøya er derimot eintydig mytologisk og oppteke på 1800-talet, det er kjent sidan 1810 (NPL, 2013: 173). Søk på tenkjelege skriftvariantar gjev under 1000 berarar til saman, 640 Frøya, 168 Freya, 69 Freyja, 107 Freja og 8 Freia («Hvor mange heter», nett). Eit anna gudinnenamn er Siv (av norrønt Sif). Det kom ikkje i bruk før på 1900-talet, fyrste gong brukt i 1918. Det var særleg populært frå 1960-1985 (NPL: 260 f.), sjå kurve nedanfor her. Populariteten i den perioden kan hengja saman med at korte førenamn var særleg mykje brukte som fyrstenamn i dobbeltnamn (jf. Nedrelid, 2015). 
Tabell 6. Namnet Siv («Hvor mange heter», nett)

\section{Siv}

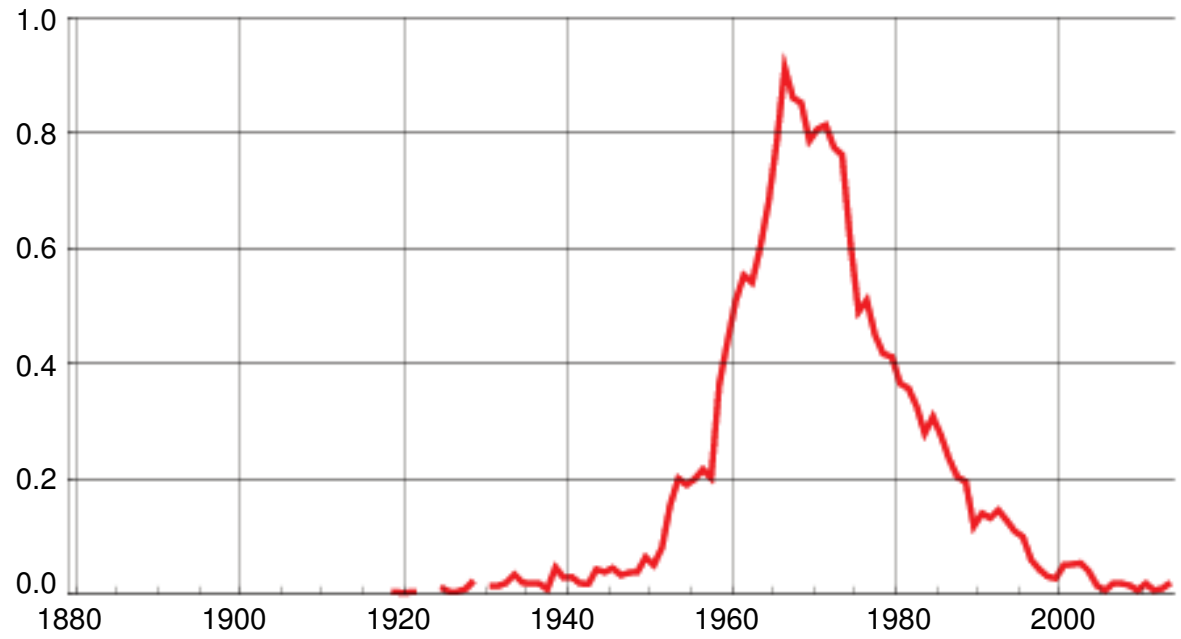

Prosent

Mellomalderlege kongenamn som vart tekne i bruk, er td. Sverre og Tryg(g)ve. Namnet Sverre vart fyrst brukt i 1817, seinare vart det svært populært utover 1800- og inn på1900-talet (NPL, 2013: 532). Namnet Tryggve var ogso svært sjeldan brukt i etterreformatorisk tid, men det er belagt i Vestfold i 1801. Det blir brukt i Trondheim i 1842, deretter kom det i allmenn bruk i Oslo og Bergen, og etter 1900 vart det motenamn i heile landet (NPL, 2013: 571).

Gustafsson har med ein fjerde type, «Namn i nationalromantisk, eller göticistisk, litteratur där både författaren och läsaren ansåg, eller trodde, att de namn som användes var fornnordiska» (Gustafsson, 2002: 116). Svahn nemner «inlånade namn från de nordiska grannländerna», med Dagmar og Valdemar som døme (Svahn, 2005: 86). Her kan det høva å ta med det islandske namnet Hildur. Det vart fyrst brukt i 1809, tok seg opp utover 1800-talet og nådde toppen rundt 1910 (NPL, 2013: 249). I dag har det 1195 berarar («Hvor mange heter», nett).

\section{Namnerenessansens vekst og fall}

Dei to kurvane som er attgjevne ovanfor (Fridtjov og Siv), viser ei kraftig stigning og eit like bratt fall. Det er litt skilnad på når det skjer, Fridtjov hadde sine glansdagar rundt 1900, medan Siv er eit typisk etterkrigsnamn. Til jamføring kan me ta med kvinnenamnet Bergljot, som har ei liknande kurve som Fridtjov, og mannsnamnet Vidar, som ogso er eit etterkrigsnamn. 
Tabell 7. Namnet Bergljot («Hvor mange heter», nett)

Bergljot

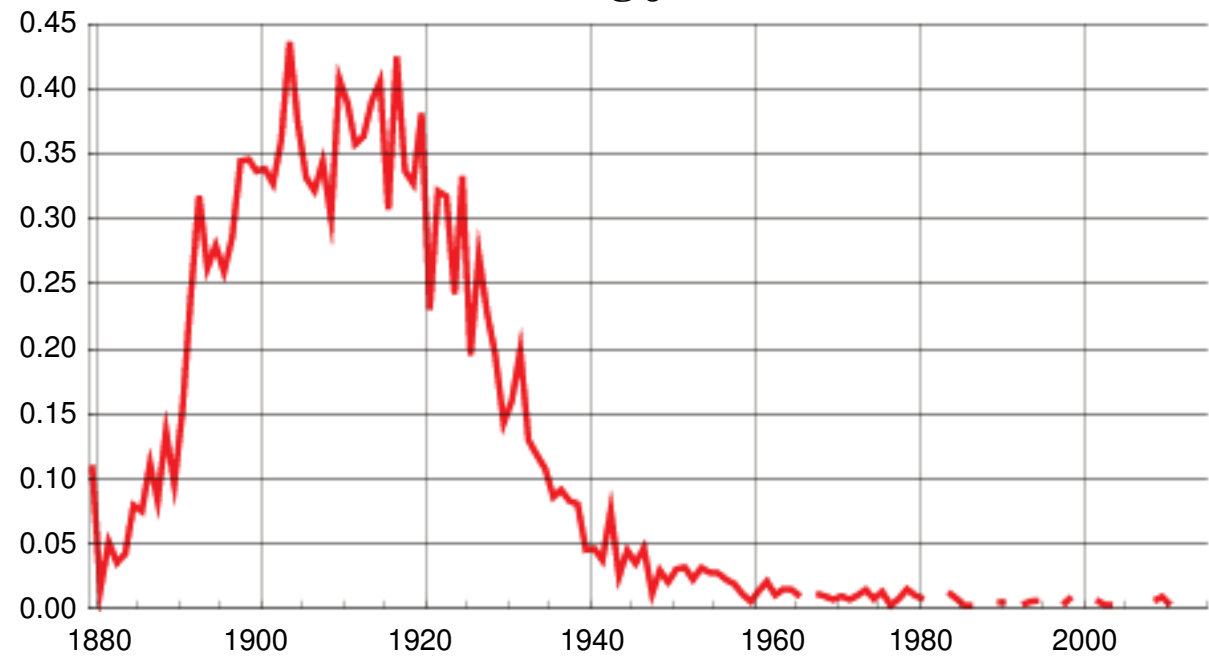

Prosent

Tabell 8. Namnet Vidar («Hvor mange heter», nett)

Vidar

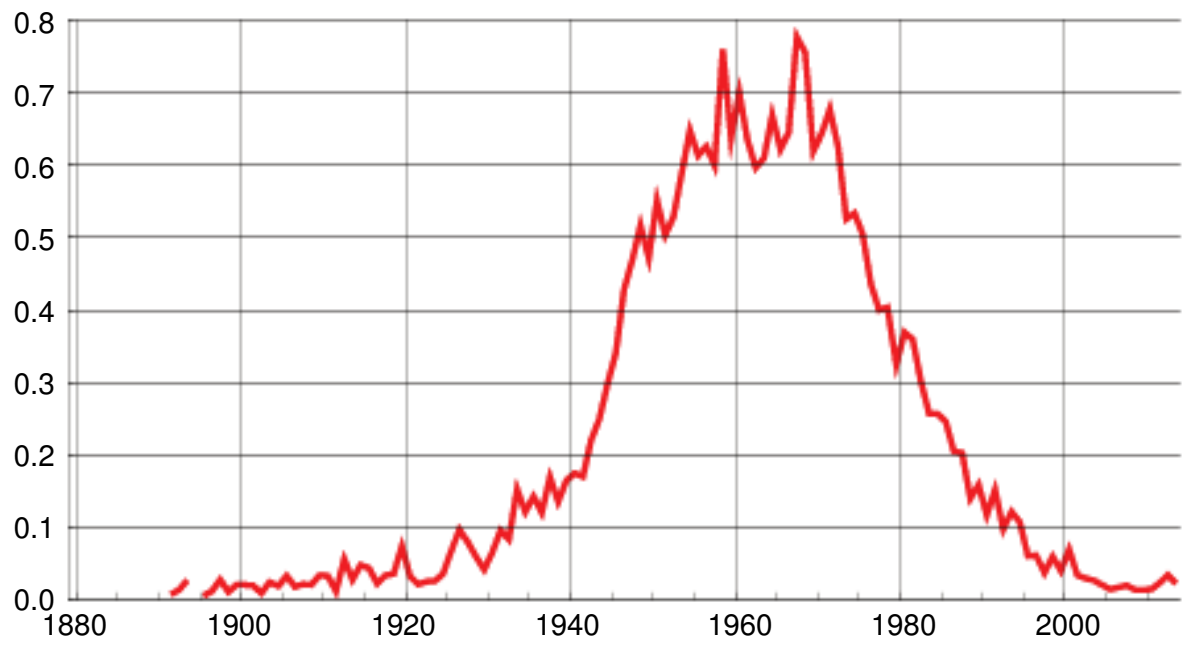

Prosent 
Same biletet får me om me sjekkar døma Sverre, Tryg $(g) v e$, Sigurd, Gudrun, Ragnfrid, Ragnvald og Svanlaug i basen «Hvor mange heter». Dei er definitivt ikkje motenamn i dag. Men fordi (somme av) dei har vore det, er det enno att ikkje so fåe som ber namn av denne typen. Tusenvis av norske menn heiter Sverre (8745), Sigurd (7124) og Trygve (5298, + 106 Tryggve). 576 norske menn heiter Ragnvald. 2719 norske kvinner heiter Gudrun, 132 heiter Ragnfrid og berre 24 heiter Svanlaug. Derimot finst det 2252 som heiter Svanhild.

Det er ikkje grunn til å tru at den nedovergåande trenden skal endra seg med det fyrste. På ti på topp-listene for begge kjønn frå 2016 (sjå «Navn 2016», http://www.ssb.no/navn/) er eitt nordisk namn inne, nemleg Ingrid, som ligg på niandeplass på jentesida. Mellom gutenamna er alle sokalla «framande» namn (sjå ovanfor), men Aksel på tiandeplass er ei nordisk form av Absalon (NPL, 2013: 23).

\section{Litteraturliste}

Aabel, M.A.L. 1867. «Norrøne Navn». In: Folkevennen. Christiania. 308-356.

Aarset, T. 1982. «Frå den nordiske namnerenessansen til i dag». In: Stemshaug, O. (ed.). Norsk personnamnleksikon. Oslo. 66-88.

Aasen, I. 1854. «Om norske Folkenavne». In: Folkevennen. Christiania. 32-49.

Aasen, I. 1855. «Register over norske Folkenavne». In: Folkevennen. Christiania. 277-306.

Aasen, I. 1878. Norsk Navnebog. Kristiania.

Gustafsson, L. 2002. Novation i norr. Nya dopnamn och namngivningsmönster $i$ Skellefftebygden 1791-1890 = Anthroponymica Suecana 12. Umeå.

Haslum, V. 2005. «Navnerenessanse eller gammel navneskikk eller begge deler? Navngivningsmønstre i store søskenflokker på Agder i perioden 1880-1940.» In: Nedrelid, G. and T. Schmidt. (eds.). Person- og stadnamn under den nordiske namnerenessansen. Rapport frå NORNAs 34. symposium, Dømmesmoen 10.-12. september 2004 = Skriftserien. Høgskolen i Agder 116. Kristiansand. 123-143.

Helleland, B. 2005. ”Oppsummering”. In: Nedrelid, G. and T. Schmidt. (eds.). Person- og stadnamn under den nordiske namnerenessansen. Rapport frå NORNAs 34. symposium, Dømmesmoen 10.-12. september $2004=$ Skriftserien. H $\phi$ gskolen i Agder 116. Kristiansand. 143-148.

Huseby, O. 1895. 1000 norske døpenavne: med korte forklaringer af deres betydning. Kristiania.

Johannessen, O-J. 2005. «Nordisk navnerenessanse i Norge før 1865?» In: Nedrelid, G. and T. Schmidt. (eds.). Person- og stadnamn under den nordiske namnerenessansen. Rapport frå NORNAs 34. symposium, Dømmesmoen 10.-12. september $2004=$ Skriftserien. Høgskolen i Agder 116. Kristiansand. 9-29.

Kruken, K. 1982. «Frå reformasjonen til den nordiske namnerenessansen». In: Stemshaug, O. (ed.). Norsk personnamnleksikon. Oslo. 44-66.

Kruken, K. 1993. «Spirene til den nordiske namnerenessansen». Nytt om namn 17. 21-24.

Kruken, K. and O. Stemshaug. 1995. Norsk personnamnleksikon. 2. utgåva. Ved Kristoffer Kruken. Oslo.

Kruken, K. 2013. Norsk personnamnleksikon. 3. utgåva. Ved Kristoffer Kruken. Oslo.

Lind, E.H. 1905-15. Norsk-isländska dopnamn och fingerade namn från medeltiden. Uppsala-Leipzig.

Meldgaard, E.V. 1997. «Fornavnemoder i Danmark 1820-2020». Studia Anthroponymica Scandinavica 15. 101-113. 
Munch, P.A. 1849. «Nogle Ord til Overvejelse om vore brugelige Personsnavne, og om at holde vore nationale Navne i Agt og Ere». In: Norsk Folke-Kalender. Christiania. 80-89.

Munch, P.A. 1854. «Fremdeles om Valget af Personsnavne, og Vedligeholdelsen af vore nationale Navne». In: Norsk Folke-Kalender. Christiania. 33-45.

Munch, P.A. 1857. «Om Betydningen af vore nationale Navne tilligemed Vink angaaende deres rette Skrivemaade og Udtale». In: Norsk Maanedsskrift. Christiania. 1-64, 122-166, 239-274, 346-373, 438-459, 481-498.

Nedrelid, G. 1996. «Lokale variasjonar i namneskikken på Agder i 1801». In: NORNA-rapporter 60. Uppsala. 211-229.

Nedrelid, G. 1997. «'Eit namn lyt allting hava’. Ivar Aasens Norsk Navnebog og den nordiske namnerenessansen». In: Gransking av norsk mål $i$ hundre år etter Ivar Aasen. Rapport frå faghistorisk seminar $i$ Trondheim 3. og 4. oktober 1996. = Det Kongelige Norske Videnskabers selskab. Skrifter 3. Trondheim. 35-49.

Nedrelid, G. 2005a. «Endring i oppkallingsskikken i eit vestnorsk bygdesamfunn». In: Nyström, S. (ed.). Utvecklingstendenser och drivkrafter inom nordiskt namnskick $=$ NORNA-rapporter 80. Uppsala. 217-245.

Nedrelid, G. 2005b. «Flettfrid, Kjøtulv og meir vanlege nydanningar». In: Nedrelid, G. and T. Schmidt. (eds.). Person- og stadnamn under den nordiske namnerenessansen. Rapport frå NORNAs 34. symposium, Dømmesmoen 10.-12. september $2004=$ Skriftserien. Høgskolen i Agder 116. Høgskolen i Agder 116. Kristiansand. 63-75.

Nedrelid, G. 2015. «Amfibrakkiske dobbeltnamn på 1900-talet». In: Aldrin, E. m.fl. (ed.). Innovationer i namn och namnmönster. Handlingar från NORNA:s 43:e symposium i Halmstad den 6-8 november 2013 = NORNA-rapporter $92.178-196$.

Nedrelid, G. and T. Schmidt. (eds.). 2005. Person- og stadnamn under den nordiske namnerenessansen. Rapport frå NORNAs 34. symposium, Dømmesmoen 10.-12. september $2004=$ Skriftserien. Hogskolen i Agder 116. Kristiansand.

NPL $=$ Norsk personnamnleksikon (Stemshaug, Ola, 1982, Kruken, Kristoffer og Stemshaug, Ola, 1995, Kruken, Kristoffer og Stemshaug, Ola, 2013).

Sundt, E. 1864. «Sprogets Bygde-Skikke». In: Folkevennen. Christiania. 95-117.

Storm, G. 1893. «Vore Forfædres Tro paa Sjælevandring og deres Opkaldelsessystem». In: Arkiv för nordisk filologi 9 . 199-222.

Støylen, B. 1887. Norske døbenavne med deres betydning og oprindelse. Kristiania.

Svahn, M. 2005. «Nordisk namnrenässans i dopnamnsskicket i stadsmiljö i Syd- och Västsverige». In: Nedrelid, G. and T. Schmidt. (eds.). Person- og stadnamn under den nordiske namnerenessansen. Rapport frå NORNAs 34. symposium, Dømmesmoen 10.-12. september $2004=$ Skriftserien. Høgskolen i Agder 116. Kristiansand. 85-93.

Veka, O. 2016. Norsk etternamnsleksikon. 2. utgåva. Revidert, oppdatert og utvida. Oslo.

Vágslid, E. 1932. Norsk navnesed: ei utgreiding um norske mannenovn. Oslo.

\section{Nettadresser}

«Hvor mange heter», nett = http://www.ssb.no/navn/ [lasta januar og februar 2017].

Navneforskning, nett $=$ http://navn.ku.dk/maanedens_navn/johannes/ [lasta 30.01.2017].

Fridtjof Nansen, snl, nettversjonen = https://snl.no/Fridtjof_Nansen [lasta 02.02.2017]. 